Check for updates

Cite this: RSC Adv., 2019, 9, 34350

DOI: 10.1039/c9ra90078k

www.rsc.org/advances

\section{Correction: A highly selective fluorescent probe for human NAD(P)H:quinone oxidoreductase 1 (hNQO1) detection and imaging in living tumor cells}

\author{
Ya Zhu, ${ }^{a}$ Jialing Han, ${ }^{a}$ Qian Zhang, ${ }^{a}$ Zhou Zhao, ${ }^{a}$ Jin Wang, ${ }^{a}$ Xiaowei Xu, ${ }^{\text {*a }}$ \\ Haiping $\mathrm{HaO}^{\star a}$ and Jun Zhang ${ }^{\star b}$
}

Correction for 'A highly selective fluorescent probe for human NAD(P)H:quinone oxidoreductase 1 (hNQO1) detection and imaging in living tumor cells' by Ya Zhu et al., RSC Adv., 2019, 9, 26729-26733.

The authors regret that some articles reporting probes for detecting human $\mathrm{NAD}(\mathrm{P}) \mathrm{H}$ :quinone oxidoreductase 1 were not cited in the original article. The missing references are listed below as ref. 1-6, and should be cited in the original paper at the end of the following sentence on page 26729:

Herein, we designed and synthesized a novel fluorescent probe $\mathbf{1}$ for detection of hNQO1 based on TCF-OH as a chromophore and quinone propionic acid (QPA) as a recognition group..$^{1-6}$

The authors sincerely apologise for this oversight.

The Royal Society of Chemistry apologises for these errors and any consequent inconvenience to authors and readers.

\title{
References
}

1 Z. M. Cheng, W. O. Valenca, G. G. Dias, J. Scott, N. D. Barth, F. de Moliner, G. B. P. Souza, R. J. Mellanby, M. Vendrell and E. N. da Silva, Natural product-inspired profluorophores for imaging NQO1 activity in tumour tissues, Bioorg. Med. Chem., 2019, 27, 3938-3946.

2 S. U. Hettiarachchi, B. Prasai and R. L. McCarley, Detection and Cellular Imaging of Human Cancer Enzyme Using a Turn-On, Wavelength-Shiftable, Self-Immolative Profluorophore, J. Am. Chem. Soc., 2014, 136, 7575-7578.

3 N. Kwon, M. K. Cho, S. J. Park, D. Kim, S. J. Nam, L. Cui, H. M. Kim and J. Yoon, An efficient two-photon fluorescent probe for human $\mathrm{NAD}(\mathrm{P}) \mathrm{H}$ :quinone oxidoreductase (hNQO1) detection and imaging in tumor cells, Chem. Commun., 2017, 53, 525-528.

4 Y. Nakamura, Z. H. Shen, T. Harada, T. Nagaya, K. Sato, S. Okuyama, F. Ogata, P. L. Choyke, R. L. McCarley and H. Kobayashi, Characteristics of ovarian cancer detection by a near-infrared fluorescent probe activated by human NAD(P)H:quinone oxidoreductase isozyme 1 (hNQO1), Oncotarget, 2017, 8, 61181-61192.

5 D. Pan, F. Y. Luo, X. J. Liu, W. Liu, W. Chen, F. Liu, Y. Q. Kuang and J. H. Jiang, A novel two-photon fluorescent probe with a long Stokes shift and a high signal-to-background ratio for human $\mathrm{NAD}(\mathrm{P}) \mathrm{H}$ :quinone oxidoreductase 1 (hNQO1) detection and imaging in living cells and tissues, Analyst, 2017, 142, 2624-2630.

6 Z. H. Shen, B. Prasai, Y. Nakamura, H. Kobayashi, M. S. Jackson and R. L. McCarley, A Near-Infrared, Wavelength-Shiftable, Turn-on Fluorescent Probe for the Detection and Imaging of Cancer Tumor Cells, ACS Chem. Biol., 2017, 12, 1121-1132. 